\title{
Digestibility and metabolism of copper in diets for pigs and influence of dietary copper on growth performance, intestinal health, and overall immune status: a review
}

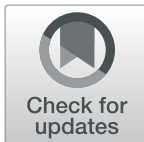

Charmaine D. Espinosa ${ }^{1}$ and Hans H. Stein ${ }^{1,2^{*}}$ (D)

\begin{abstract}
The current contribution reviews absorption and metabolism of copper (Cu), Cu deficiency, Cu toxicity, Cu bioavailability, and effects of pharmacological levels of $\mathrm{Cu}$ on growth performance and intestinal health of pigs. Copper is a micro mineral involved in metabolic reactions including cellular respiration, tissue pigmentation, hemoglobin formation, and connective tissue development. Copper is mostly absorbed in the upper gastrointestinal tract, particularly in the duodenum, but some $\mathrm{Cu}$ is absorbed in the stomach. One way to evaluate the efficacy of sources of $\mathrm{Cu}$ is to measure relative bioavailability where responses include tissue concentrations of $\mathrm{Cu}$, concentrations of metalloproteins, and enzymatic activity of animals fed test diets containing graded levels of $\mathrm{Cu}$. The requirement for $\mathrm{Cu}$ by pigs is 5 to $10 \mathrm{mg} / \mathrm{kg}$ diet, however, Cu can be included at growth-promoting levels (i.e., 75 to $250 \mathrm{mg} / \mathrm{kg}$ diet) in diets for weanling and growing pigs to reduce post-weaning diarrhea and improve growth performance. The consistently observed improvement in growth performance upon Cu supplementation is likely a result of increases in lipase activity, growth hormone secretion, and expression of genes involved in postabsorptive metabolism of lipids. The growth-promoting effects of dietary Cu have also been attributed to its bacteriostatic and bactericidal properties because Cu may change bacterial populations in the intestine, and thereby reduce inflammation caused by pathogens. However, further research is needed to determine potential interactions between $\mathrm{Cu}$ and non-nutritive feed additives (e.g., enzymes, probiotics, phytobiotics), and the optimum quantity of $\mathrm{Cu}$ as well as the optimum duration of feeding supplemental $\mathrm{Cu}$ in diets for pigs should be further investigated. These gaps needs to be addressed to maximize inclusion of $\mathrm{Cu}$ in diets to improve growth performance while minimizing diseases and mortality.
\end{abstract}

Keywords: Copper, Copper nutrition, Intestinal health, Metabolism, Pharmacological concentrations, Pigs

\footnotetext{
* Correspondence: hstein@illinois.edu

1Department of Animal Sciences, University of Illinois, Urbana 61801, USA

2Division of Nutritional Sciences, University of Illinois, Urbana 61801, USA
}

(c) The Author(s). 2021 Open Access This article is licensed under a Creative Commons Attribution 4.0 International License, which permits use, sharing, adaptation, distribution and reproduction in any medium or format, as long as you give appropriate credit to the original author(s) and the source, provide a link to the Creative Commons licence, and indicate if changes were made. The images or other third party material in this article are included in the article's Creative Commons licence, unless indicated otherwise in a credit line to the material. If material is not included in the article's Creative Commons licence and your intended use is not permitted by statutory regulation or exceeds the permitted use, you will need to obtain permission directly from the copyright holder. To view a copy of this licence, visit http://creativecommons.org/licenses/by/4.0/ The Creative Commons Public Domain Dedication waiver (http://creativecommons.org/publicdomain/zero/1.0/) applies to the data made available in this article, unless otherwise stated in a credit line to the data. 


\section{Introduction}

Minerals are inorganic elements needed by pigs for maintenance, growth, and reproduction [1]. Historically, mineral nutrition of domestic animals was considered of limited importance with the exception of common salt, which was recognized in Biblical times as a substance of value for human and animal consumption [2]. Discovery of the essentiality of minerals dates back to the late eighteenth century when it was recognized that deficiency of minerals caused certain diseases [1]. The nutritional significance of minerals was demonstrated in 1791 when Fordyce demonstrated that canaries require an adequate Ca supply for optimum health and egg production [3], but most of the early research with minerals was conducted to alleviate health problems [3].

Minerals have structural, physiological, catalytic, and regulatory functions in animals [4] and they are classified into 2 groups based on the amount that is required in the diet. Minerals needed by more than $100 \mathrm{mg} / \mathrm{kg}$ diet on a dry matter basis are called macro minerals, and this group includes $\mathrm{Ca}, \mathrm{Cl}, \mathrm{K}, \mathrm{Mg}, \mathrm{Na}, \mathrm{P}$, and $\mathrm{S}$ [1]. These minerals play a major role in acid-base balance, structural and regulatory functions in bones and teeth, and nerve transmission. Minerals that are required in quantities less than $100 \mathrm{mg} / \mathrm{kg}$ diet are called micro minerals, and primarily serve as components of enzymes, coenzymes, and hormones [5]. Micro minerals include $\mathrm{Cr}, \mathrm{Fe}, \mathrm{I}, \mathrm{Mn}, \mathrm{Mo}, \mathrm{Co}, \mathrm{Se}, \mathrm{Zn}$, and $\mathrm{Cu}$ [6].

Copper $(\mathrm{Cu})$ is an essential component of several metalloenzymes including cytochrome $\mathrm{C}$ oxidase, lysyl oxidase, cytosolic $\mathrm{Cu}-\mathrm{Zn}$ superoxide dismutase (SOD1), extracellular $\mathrm{Cu}-\mathrm{Zn}$ superoxide dismutase 3 (SOD3), monoamine oxidase, and tyrosinase [7, 8]. Copper, therefore, plays a role in oxidation-reduction reactions, transport of oxygen and electrons, and protection against oxidative stress $[8,9]$. Copper is involved in metabolic reactions including cellular respiration, tissue pigmentation, hemoglobin formation, and connective tissue development [10, 11]. Copper has been recognized as an essential mineral since 1928 when it was demonstrated that $\mathrm{Cu}$ is needed for red blood cell synthesis in rats. Rats suffering from anemia were fed animal or vegetable based diets supplemented with ash and were able to recuperate from the disease. It was subsequently discovered that ash contained $\mathrm{Cu}$ sulfide [12]. This discovery led to research that demonstrated the essentiality of $\mathrm{Cu}$ not only for preventing microcytic hypochromic anemia, but also for maintenance and growth $[12,13]$.

The objective of this contribution is to review current understanding of digestibility, absorption, and metabolism of $\mathrm{Cu}, \mathrm{Cu}$ deficiency, $\mathrm{Cu}$ toxicity, $\mathrm{Cu}$ bioavailability, and relationships between $\mathrm{Cu}$ and other nutrients. Effect of pharmacological levels of $\mathrm{Cu}$ on growth performance, gut microbiome, and intestinal health of pigs will also be discussed.

\section{Digestibility, absorption, and metabolism of copper}

Mineral digestibility reflects the dissolution and absorption of minerals from the gastrointestinal lumen. Digestibility and absorption of minerals is difficult to accurately determine due to endogenous mineral secretions into the gastrointestinal tract via pancreatic juice, bile, and mucosal cells [14]. Digestibility of $\mathrm{Cu}$ and $\mathrm{Zn}$ is also difficult to assess due to interference of homoeostatic regulation, which normally limits absorption of these minerals when animals are fed beyond the requirement [15]. The digestibility of $\mathrm{Cu}$ for growing pigs range from $30 \%$ to $55 \%[15,16]$, and the relatively low digestibility of $\mathrm{Cu}$ is due to antagonisms between $\mathrm{Cu}$ and other microminerals [17]. Low $\mathrm{pH}$ in the stomach may reduce digestibility of $\mathrm{Cu}$ by causing dissociation of inorganic salts of dietary $\mathrm{Cu}$ [18]. As $\mathrm{pH}$ increases in the small intestine, $\mathrm{Zn}$ and $\mathrm{Cu}$ can be trapped in insoluble hydroxide precipitates, rendering these minerals unavailable for absorption [19]. The dietary source of $\mathrm{Cu}$ also affects its digestibility in pigs [15]. Chelation of dietary trace minerals with proteinates (i.e., peptides, amino acids) improve apparent total tract digestibility and retention of $\mathrm{Cu}$ in pigs by preventing formation of insoluble complexes along the gastrointestinal tract $[16,20]$.

Copper is mostly absorbed in the upper gastrointestinal tract, particularly in the duodenum, but some $\mathrm{Cu}$ is absorbed in the stomach [21]. In non-ruminants, $\mathrm{Cu}$ is primarily absorbed through a transcellular saturable process [22], but $\mathrm{Cu}$ can be absorbed through solvent drag, which involves movement of $\mathrm{Cu}$ through the tight junction pores [23]. Solvent drag allows free mineral ions to be solubilized in water through water dipole-ion interaction. Minerals suspended in water can be absorbed when water passes through the pores within the protein meshwork forming the tight junction [23].

Copper exist in two forms of valency depending on its state of oxidation. Most dietary $\mathrm{Cu}$ is in the $\mathrm{Cu}^{2+}$ form, but for $\mathrm{Cu}$ to be absorbed, it must be reduced to $\mathrm{Cu}^{+}$, which is catalyzed by a Cu-reductase enzyme that is expressed by glands at the brush border [24]. This metalloreductase belongs to the Steap protein family, and is a ferrireductase that stimulates cellular uptake of $\mathrm{Fe}$ and $\mathrm{Cu}$ [25]. Following the reduction of dietary $\mathrm{Cu}^{2+}$ into $\mathrm{Cu}^{+}, \mathrm{Cu}^{+}$crosses the apical membrane and enters the enterocyte through $\mathrm{Cu}$ transport protein 1 (CTR1). Copper transport protein 1, which has a high affinity for $\mathrm{Cu}$, is the main $\mathrm{Cu}$ transporter in enterocytes. Copper transport protein 1 is present in most tissues with significant quantities in the liver [26] because of the high need for $\mathrm{Cu}$ in hepatic cells. The amount of CTR1 in the apical membrane decreases via degradation in endosomal compartments if $\mathrm{Cu}$ is in excess of the requirement [27]. Other $\mathrm{Cu}$ transporters involved in $\mathrm{Cu}$ uptake are $\mathrm{Cu}$ transport protein 2 (CTR2) and divalent metal 
transporter (DMT1), but their affinity for $\mathrm{Cu}$ is less than that of CTR1 [28]. The DMT1 is located mainly on the brush border and transports $\mathrm{Cu}, \mathrm{Fe}, \mathrm{Zn}$, and $\mathrm{Mn}$ across the apical membrane [29]. Thus, CTR1, CTR2, and DMT1 are the transport proteins specifically involved in increasing cellular $\mathrm{Cu}$ concentration if the body is in need of $\mathrm{Cu}$.

Upon uptake of $\mathrm{Cu}^{+}$from the apical membrane, $\mathrm{Cu}^{+}$is transferred to chaperone proteins [30]. Chaperone proteins are involved in maintaining homeostatic $\mathrm{Cu}$ concentration in the body, and are associated with specific metalloenzymes and other $\mathrm{Cu}$-containing proteins [27]. One of the chaperone proteins delivers $\mathrm{Cu}^{+}$to $\mathrm{Cu} / \mathrm{Zn}$ superoxide dismutase, which is an antioxidant enzyme. Another chaperone protein is the cytochrome $\mathrm{C}$ oxidase $\mathrm{Cu}$ chaperone (COX17), which transports $\mathrm{Cu}^{+}$in the mitochondria to cytochrome $\mathrm{C}$ oxidase, which is involved in energy transfer from NADH or $\mathrm{FADH}_{2}$ to ATP [29]. Other chaperone proteins include antioxidant protein 1 (ATOX1), which delivers $\mathrm{Cu}$ through the cytosol to the Golgi apparatus of intestinal cells [31]. Copper is then transferred to the $\mathrm{Cu}$ transporting ATPase 1 protein (ATP7A), which can bind and translocate $6 \mathrm{Cu}^{+}$ ions into the basolateral membrane [32]. This ATPase also sequesters excess $\mathrm{Cu}$ to avoid $\mathrm{Cu}$ toxicity [33]. At the basolateral membrane, $\mathrm{Cu}^{+}$is then converted to $\mathrm{Cu}^{2+}$ via a $\mathrm{Cu}$ oxidase for release into the interstitial space.

The homeostatic regulation of $\mathrm{Cu}$ absorption primarily involves the action of specific transporters and chaperone proteins [34]. The rate of $\mathrm{Cu}$ absorption is influenced by the $\mathrm{Cu}$ status of the animal, and $\mathrm{Cu}$ digestibility may be increased if animals are $\mathrm{Cu}$-deficient [35]. If animals are deficient in $\mathrm{Cu}$, there is an increase in the synthesis of $\mathrm{Cu}$ transport proteins and a $\mathrm{Cu}$-ATPase pump is used to move $\mathrm{Cu}$ across the basolateral membrane into the extracellular fluid [35]. If the $\mathrm{Cu}$ concentration of the animal is adequate, the amount of $\mathrm{Cu}$ transport proteins for uptake is low, and the liver can synthesize metalloenzymes and store $\mathrm{Cu}$ for future use. If dietary $\mathrm{Cu}$ is provided in excess of the requirement, enterocytes produce a sulfhydryl-rich protein called metallothionein, which binds to the freely ionized $\mathrm{Cu}$. This results in a subsequent reduction of $\mathrm{Cu}$ absorption, which helps prevent $\mathrm{Cu}$ toxicity [36, 37]. Metallothionein binds other metals such as $\mathrm{Zn}$ and $\mathrm{Cd}$ $[37,38]$. Supplementing animals with greater quantities of $\mathrm{Cu}$ increases gene and protein expression of $\mathrm{Cu}$ specific transporters and chaperone proteins [39] because high concentration of $\mathrm{Cu}$ triggers ATP7A to become more active in releasing $\mathrm{Cu}^{+}$at a higher rate [40]. However, research is needed to determine how pharmacological concentrations of $\mathrm{Cu}$ modulate expression of $\mathrm{Cu}$ transporters and chaperone proteins at the transcription level as well as at the level of translation.
In the hepatic portal vein, most of the absorbed $\mathrm{Cu}^{2+}$ is bound to albumin and transcuprein [41] for transport to the liver, where it is taken up by hepatocytes as $\mathrm{Cu}^{+}$ using $\mathrm{Cu}$ reductase. The CTR1 protein then moves $\mathrm{Cu}^{+}$ across the hepatocyte cell membrane. For $\mathrm{Cu}$ to be transported from the liver to peripheral tissues, Atox1 delivers $\mathrm{Cu}$ to the transmembrane Golgi complex. Copper is then transferred to the $\mathrm{Cu}$ transporting ATPase 2 protein (ATP7B) [32]. The $\mathrm{Cu}$ bound to ATP7B can then be utilized to produce $\mathrm{Cu}$-containing proteins for export from the liver. Most $\mathrm{Cu}$ in serum is contained in ceruloplasmin, which is the major protein carrier for export of $\mathrm{Cu}$ from liver to target organs [42].

Ceruloplasmin is involved in Fe metabolism by having ferroxidase activity, which catalyzes the conversion of $\mathrm{Fe}^{2+}$ to $\mathrm{Fe}^{3+}$ [43]. The biological role of ceruloplasmin in pigs was reported by Ragan et al. [44] who demonstrated the impact of ceruloplasmin on plasma Fe in pigs fed diets deficient in $\mathrm{Cu}$. Deficiency of $\mathrm{Cu}$ resulted in reduced concentration of serum ceruloplasmin with a subsequent manifestation of anemia in pigs. Iron deficiency was only corrected by administration of homologous ceruloplasmin or $\mathrm{Cu}$ to $\mathrm{Cu}$-deficient pigs [44]. Porcine ceruloplasmin can be classified as ceruloplasmin I or ceruloplasmin II [45]. Ceruloplasmin I has greater copper content and specific enzymatic activity compared with ceruloplasmin II. Newly born piglets typically have high concentrations of liver $\mathrm{Cu}$ with ceruloplasmin II as the predominant form of ceruloplasmin. As pigs grow older, the concentration of ceruloplasmin I increases whereas ceruloplasmin II concentration remains constant [45].

\section{Deficiency and toxicity of copper}

Animals deprived of $\mathrm{Cu}$ develop critical dysfunctions and hypocuprosis [46-49]. Microcytic anemia is a sign of $\mathrm{Cu}$ deficiency due to its role in Fe metabolism, specifically in hemoglobin formation and development $[47,50,51]$. Ceruloplasmin, which functions physiologically as a copperdependent ferroxidase to promote transferrin formation, is essential for the catalysis of $\mathrm{Fe}^{2+}$ to $\mathrm{Fe}^{3+}$ [42]. Pigs suffer from bone abnormalities and unusual leg conditions with various degrees of crookedness if dietary $\mathrm{Cu}$ is deficient because of deficiency in monoamine oxidase, which is needed for cartilage formation [48, 49]. Depigmentation, failure of hair keratinization, and cardiovascular disorders have also been demonstrated as signs of $\mathrm{Cu}$ deficiency [52, 53]. More than $60 \%$ of pigs fed $\mathrm{Cu}$-deficient diets died from coronary artery disease [54] characterized by intimal lesions in muscular arteries of $\mathrm{Cu}$-deficient pigs [55]. Integrity of arteries in the cardiovascular system relies heavily on the quality and quantity of collagen and elastin, and $\mathrm{Cu}$-dependent oxidases (i.e., benzylamine oxidase and lysyl oxidase) are needed for collagen 
and elastin metabolism [56]. Pigs with hypocuprosis have impaired humoral response [57]. Copper plays an important role in the development and function of $\mathrm{T}$ and $\mathrm{B}$ cells, neutrophils, and macrophages $[58,59]$, and deficiency of $\mathrm{Cu}$ affects the immune system because of deficiency in cytochrome $\mathrm{C}$ oxidase and superoxide dismutase [57]. Low concentration of cytochrome $\mathrm{C}$ oxidase results in impairment of the respiration burst in neutrophils, and subsequently a decrease in immunological function [60].

The clinical signs and symptoms that are typically observed in pigs with $\mathrm{Cu}$ deficiency have always been associated with the role of $\mathrm{Cu}$ as a component of metalloenzymes needed for several metabolic reactions such as cellular respiration, hemoglobin formation, cartilage formation, and keratinization [48]. A reduction in growth performance and feed intake occurs when $\mathrm{Cu}$ is deficient in diets for all species; however, an unusual leg condition develops specifically in $\mathrm{Cu}$-deficient pigs [61]. Pigs fed diets that are deficient in $\mathrm{Cu}$ have signs of central nervous system disorders such as ataxia, posterior paresis, and horizontal nystagmus, and these observations is possibly due to a deficiency of cytochrome $\mathrm{C}$ oxidase needed for phospholipid synthesis [58, 62]. Deficiency in $\mathrm{Cu}$ may be related to the degree of saturation of the animals' lipid reserves and cholesterol profile because dietary $\mathrm{Cu}$ is believed to influence lipid metabolism in animals [63, 64]. Addition of increasing levels of dietary $\mathrm{Cu}$ as $\mathrm{CuSO}_{4}$ reduced the concentration of serum polyunsaturated fatty acids in pigs fed diets containing $5 \%$ fat as stabilized medium-chain triglycerides, whereas the concentration of serum polyunsaturated fatty acids increased in pigs fed diets without added fat [65]. Copper supplementation may also affect carcass fatty acid composition of pigs because supplementation of $\mathrm{Cu}$ in diets resulted in increased proportion of unsaturated fatty acids in the outer backfat, inner backfat, and perinephric backfat of pigs $[66,67]$. Deficiency of $\mathrm{Cu}$ causes hypercholesteremia and hypertriglyceridemia [68], and the reason for these conditions has been attributed to the role of $\mathrm{Cu}$ in increasing lipoprotein lipase and triolein hydrolase activities [64]. The effect of $\mathrm{Cu}$ deficiency on accumulation of long chain fatty acids has been attributed to increased expression of fatty acid synthase with reduced concentration of ceruloplasmin in the serum [69] because $\mathrm{Cu}$ is needed for ceruloplasmin to function. As $\mathrm{Cu}$ concentration increases, and is greater relative to the requirement, ceruloplasmin activity increases [70], which inhibits lipid peroxidation by inhibiting glutathione peroxidase and catalase [71].

Pigs are less sensitive to $\mathrm{Cu}$ toxicity than ruminants [5]. Sheep and lambs can only tolerate a $\mathrm{Cu}$ level of 20 $\mathrm{mg} / \mathrm{kg}$ and $100 \mathrm{mg} / \mathrm{kg}$ (dry matter basis), respectively [72, 73]. Differences in the tolerance level for $\mathrm{Cu}$ among species can be attributed to the capacity of the animal to excrete $\mathrm{Cu}$ in the bile, and in general, pigs excrete more $\mathrm{Cu}$ compared with ruminants [5]. Pigs also absorb $\mathrm{Cu}$ more efficiently compared with ruminants $[74,75]$. If the dietary level of $\mathrm{Cu}$ is in excess of the requirement, $\mathrm{Cu}$ accumulates in the liver and other vital organs. This may result in increased concentration of unbound free ionized $\mathrm{Cu}$, which is a strong oxidant leading to haemolysis [76]. In pigs, $\mathrm{Cu}$ can be toxic if more than 250 $\mathrm{mg} / \mathrm{kg}$ of diet is fed for an extended period because this leads to hemolysis of red blood cells characterized by jaundice and necrosis [76, 77]. Inclusion of $750 \mathrm{mg}$ of $\mathrm{Cu}$ per $\mathrm{kg}$ of diet in growing pigs resulted in increased $\mathrm{Cu}$ and aspartate transaminase (AST) concentrations in the serum [78], and the observed increase in serum AST concentration indicates damage to tissues where AST is abundant (i.e., kidney, liver) [79]. Signs of jaundice were observed in pigs when fed diets with $750 \mathrm{mg} / \mathrm{kg}$ of $\mathrm{Cu}$, which was proposed to be a result of liver damage due to the relationship between the increased serum AST concentration and the degree of jaundice [78]. However, addition of $500 \mathrm{mg} / \mathrm{kg}$ of $\mathrm{Zn}$ or Fe to diets containing $750 \mathrm{mg} / \mathrm{kg}$ of $\mathrm{Cu}$ prevented clinical signs of copper toxicity and resulted in normal serum concentration of AST [78].

High concentrations of $\mathrm{Cu}$ in the diet could also promote lipid peroxidation in cell membranes by inducing oxidative stress in diets as well as in the body [80]. Lipid peroxidation causes degradation of unsaturated fatty acids, which results in a reduction of energy in diets, and as a consequence, could negatively affect growth performance and health of pigs [81]. One method to determine the degree of peroxidation in the animal's body is through the use of malondialdehyde [82]. Malondialdehyde is commonly used as a biomarker of oxidative stress, and the thiobarbitoric acid assay is a method frequently used to determine malondialdehyde in biological fluids and tissues [83]. The degree of oxidative stress varies and is influenced by diet type and source of $\mathrm{Cu}$. Dietary factors that act as antagonists for $\mathrm{Cu}$ absorption, such as high concentrations of $\mathrm{Zn}$ and phytate, alleviate the pro-oxidant effects of excess $\mathrm{Cu}$ [39]. The major sources of $\mathrm{Cu}$ fed to pigs include $\mathrm{CuSO}_{4}$ and $\mathrm{Cu}$ hydroxychloride, and these sources vary greatly in their chemical characteristics [84]. Pigs fed diets with $225 \mathrm{mg} / \mathrm{kg}$ $\mathrm{Cu}$ hydroxychloride had reduced duodenal malondialdehyde concentrations compared with pigs fed $\mathrm{CuSO}_{4}$ at the same concentration, which resulted in less oxidative stress in the intestine [39].

\section{Assessment methods for copper bioavailability}

One way to evaluate efficacy of sources of $\mathrm{Cu}$ is to measure relative bioavailability or digestibility. Relative bioavailability of dietary $\mathrm{Cu}$ is defined as the proportion of the ingested dietary $\mathrm{Cu}$ that has been chemically 
absorbed and can be utilized by the animal for maintenance and growth [85]. Bioavailability is also defined as the proportion of an ingested nutrient that is absorbed, transported to its site of action, and utilized to synthesize a physiologically active metabolite [86]. Estimates for relative bioavailability of different $\mathrm{Cu}$ sources is commonly obtained through slope-ratio assays [87]. In this assay, diets with graded levels of $\mathrm{Cu}$ are formulated, and responses indicative of $\mathrm{Cu}$ status of the animals are evaluated [88]. Responses include tissue concentrations of $\mathrm{Cu}$, concentrations of metalloproteins, or enzymatic activity of animals fed the test diets. The slope of the regression line obtained from animals fed the test source of $\mathrm{Cu}$ is compared with that from animals fed a reference $\mathrm{Cu}$ source $[89,90]$.

Cupric sulfate pentahydrate is the most commonly used reference standard for estimating bioavailability of $\mathrm{Cu}$ from different sources [91]. The relative bioavailability of $\mathrm{Cu}$ is evaluated in vivo using $\mathrm{Cu}$ radioisotopes and plethoric dietary supplementation [85]. Liver, bile, and gall bladder are usually harvested and $\mathrm{Cu}$ concentrations are measured to assess relative $\mathrm{Cu}$ bioavailability [9294]. Plasma $\mathrm{Cu}$ concentrations, metalloproteins, and metalloenzymatic activities (ceruloplasmin, cytochrome $\mathrm{C}$ oxidase, and $\mathrm{Cu}$-superoxide dismutase) can also be used as indicators of $\mathrm{Cu}$ status [95]. In pigs, $\mathrm{Cu}$-Lys and $\mathrm{Cu}$-Met are more bioavailable than $\mathrm{CuSO}_{4}$, whereas cupric carbonate and $\mathrm{Cu}$ citrate are less bioavailable than $\mathrm{CuSO}_{4}$ (Table 1). In general, plant feed ingredients are variable in the bioavailability of $\mathrm{Cu}$ and have lower bioavailability of $\mathrm{Cu}$ than animal and sources of $\mathrm{Cu}$ [85] because the majority of $\mathrm{Cu}$ in plant feed ingredients is bound to phytate [88]. However, $\mathrm{Cu}$ from pork liver has low bioavailability compared with other sources due to high concentration of $\mathrm{Zn}$ in the liver, which may inhibit $\mathrm{Cu}$ availability [88]. Copper oxide also has low bioavailability when fed to ruminants, poultry, and pigs $[93,96]$ due to the inability of copper oxide to solubilize in acidic conditions with relatively high passage rate in the gastrointestinal tract [95].

Table 1 Relative bioavailability of Cu sources for pigs ${ }^{a}$

\begin{tabular}{ll}
\hline Source & Relative bioavailability \\
\hline $\mathrm{CuSO}_{4}$ & 100 \\
$\mathrm{Cu}-\mathrm{Met}$ & 110 \\
$\mathrm{Cu}-\mathrm{Lys}$ & 112 \\
Cupric carbonate & 85 \\
Cupric oxide & 0 \\
Cupric sulfide & 10 \\
Cu citrate & 84 \\
\hline
\end{tabular}

aalues were adapted from Baker and Ammerman [85]

${ }^{\text {b}}$ The relative bioavailability is expressed relative to the bioavailability of $\mathrm{Cu}$ in $\mathrm{CuSO}_{4}$
Enzyme efficacy, digestibility, and in vitro bioavailability of $\mathrm{Cu}$ in feed ingredients have been studied [97]. Results of an in vitro digestibility assay indicated that $\mathrm{CuSO}_{4}$ and $\mathrm{Cu}$ hydroxychloride were completely dissolved during stomach digestion simulation, but the solubility of $\mathrm{Cu}$ from $\mathrm{Cu}$ hydroxychloride was more influenced by the $\mathrm{pH}$ of the digesta than $\mathrm{Cu}$ from $\mathrm{CuSO}_{4}$ if fed to poultry $[98,99]$. Copper from $\mathrm{CuSO}_{4}$ was completely dissolved at $\mathrm{pH} 6.8,4.8,3.0$, and 2.0. In contrast, $\mathrm{Cu}$ from $\mathrm{Cu}$ hydroxychloride was not soluble at $\mathrm{pH} 6.8$, but solubility gradually increased as $\mathrm{pH}$ decreased [100]. The concentration of $\mathrm{Cu}$ in diets may also affect its solubility in the stomach. Solubility of $\mathrm{Cu}$ during simulated stomach digestion in pigs increased if $250 \mathrm{mg} / \mathrm{kg}$ of $\mathrm{CuSO}_{4}$ or $\mathrm{Cu}$ hydoxychloride was included in a control diet that contained $15 \mathrm{mg} / \mathrm{kg}$ of $\mathrm{Cu}$ [99]. Due to the low concentration of $\mathrm{Cu}$ in the control diet, other feed ingredients inhibit dissolution of $\mathrm{Cu}$. Therefore, supplementation of $\mathrm{CuSO}_{4}$ or $\mathrm{Cu}$ hydoxychloride to the control diet may have increased the proportion of $\mathrm{Cu}$ available for stomach dissolution in pigs [99].

\section{Copper sources and requirements for pigs}

The $\mathrm{Cu}$ that is included in pig diets usually originates from plant or animal-based feed ingredients or from mineral supplements. Most commonly used cereal grains and their co-products in swine diets contain 4.4 to 38.4 $\mathrm{mg} / \mathrm{kg}$ of $\mathrm{Cu}$ on an as-fed basis (Table 2), but the amount of $\mathrm{Cu}$ in each plant feed ingredient vary depending on the variety, type of soil on which plants grow, maturity stage, and climatic conditions during growth [18]. Oilseed meals including soybean meal, cottonseed meal, and linseed meal usually have greater $\mathrm{Cu}$ concentration compared with cereal grains [101]. Fermentation of plant feed ingredients increases concentration of crude protein and ash because soluble carbohydrates are fermented, and therefore, the concentration of $\mathrm{Cu}$ may also increase [102]. Animal protein sources commonly used in pig diets include fish meal, poultry meal, and blood meal and these ingredients are generally comparable in $\mathrm{Cu}$ concentration to plant feed ingredients ranging from 8 to $36 \mathrm{mg} / \mathrm{kg}$ [76]. Copper in milk products such as skim milk powder, lactose, casein, and whey powder ranges from 0.10 to $6 \mathrm{mg} / \mathrm{kg}$ [76].

Supplemental $\mathrm{Cu}$ is provided by fortifying complete diets and premixes with $\mathrm{Cu}$ from $\mathrm{CuSO}_{4}$, copper chloride, $\mathrm{Cu}$ amino acid complexes, or $\mathrm{Cu}$ hydroxychloride. Copper sulfate pentahydrate $\left(\mathrm{CuSO}_{4} \cdot 5 \mathrm{H}_{2} \mathrm{O}\right)$ is a blue crystalline $\mathrm{Cu}$ salt commonly used as a pesticide, fungicide, soil additive, and feed supplement [103]. Copper sulfate is soluble in water with decreased solubility upon subjection to increased acid conditions [104]. Copper sulfate is the most common form of supplemental $\mathrm{Cu}$ in animal feeding due to its availability, and its relatively low cost 
Table 2 Copper concentration in feed ingredients ${ }^{a}$

\begin{tabular}{|c|c|}
\hline Feed ingredient & $\begin{array}{l}\text { Average Cu content } \\
\text { (as-fed basis), } \mathrm{mg} / \mathrm{kg}\end{array}$ \\
\hline Corn, white & 4.4 \\
\hline Corn, yellow & 4.7 \\
\hline Rye & 5.9 \\
\hline Oats & 6.8 \\
\hline Barley & 7.2 \\
\hline Oat groats & 7.6 \\
\hline Wheat & 7.8 \\
\hline Fish meal & 8.0 \\
\hline Rice bran & 9.0 \\
\hline Wheat germ & 9.0 \\
\hline Millet, Japanese & 9.1 \\
\hline Wheat middlings & 12.1 \\
\hline Meat and bone meal & 11.0 \\
\hline Blood meal & 13.1 \\
\hline Flaxseed meal & 16.2 \\
\hline Brewer's dried grain & 16.4 \\
\hline Wheat bran & 16.4 \\
\hline Wheat gluten & 17.2 \\
\hline Cottonseed meal & 21.8 \\
\hline Linseed oil meal & 21.8 \\
\hline Soybean & 22.7 \\
\hline Meat meal & 23.1 \\
\hline Corn gluten meal & 35.1 \\
\hline Poultry meal & 35.7 \\
\hline Distillers dried gains with solubles & 38.4 \\
\hline
\end{tabular}

${ }^{a}$ All values were adapted from O'Dell [101] and NRC [76]

compared with other sources of $\mathrm{Cu}$ [105]. Results of a number of experiments have documented the effects of $\mathrm{CuSO}_{4}$ in enhancing growth performance and gut health in weanling pigs [106-109]. However, using pharmacological concentrations of $\mathrm{CuSO}_{4}$ in pig diets have resulted in antagonisms with other dietary constituents [110] and environmental concerns due to high excretion of $\mathrm{Cu}$ in feces [111]. Due to potential negative effects on the external environment, the European Union, China, and other countries recently reduced the authorized maximum concentration of $\mathrm{Cu}$ in animal feed [112]. Excessive use of $\mathrm{Cu}$ in diets fed to pigs resulted in acquired copper resistance in gram-negative bacteria (e.g., Escherichia coli, Pseudomonas syringae) and gram-positive bacteria (e.g., Bacillus subtilis, Lactococcus lactis), which may lead to antibiotic resistance and negatively influence antibiotic treatments for diseases [113-116]. Therefore, other forms of supplemented $\mathrm{Cu}$, which are generally included in diets at a lower inclusion rate and are less reactive with other nutrients, have been introduced to the feed industry.
Examples of other sources of $\mathrm{Cu}$ include chelated $\mathrm{Cu}$ and $\mathrm{Cu}$ hydroxychloride. Chelation involves binding of $\mathrm{Cu}$ to a ligand (i.e., ethylenediaminetetraacetic acid, hydrolyzed soy protein, amino acids, or polysaccharides), and it is possible that $\mathrm{Cu}$ from these sources is absorbed more efficiently and have higher retentions compared with $\mathrm{Cu}$ from $\mathrm{CuSO}_{4}[16,112,117]$. Indeed, inclusion of chelated $\mathrm{Cu}$ in diets for weanling pigs is as effective as use of $\mathrm{CuSO}_{4}$ in improving growth performance [117-119]. Addition of 100 to $200 \mathrm{mg}$ of $\mathrm{Cu}$ per $\mathrm{kg}$ complexed with amino acids such as CuLys is also as effective, and in some cases more effective, than $\mathrm{Cu}$ from $\mathrm{CuSO}_{4}$ in increasing average daily gain (ADG) and average daily feed intake (ADFI) in weanling pigs $[120,121]$. In an experiment conducted by $\mathrm{Ma}$ et al. [122], treatments included 2 supplemental levels of $\mathrm{Cu}(50$ or $250 \mathrm{mg} / \mathrm{kg}$ ) and $\mathrm{Cu}$ from either $\mathrm{Cu}$ (2-hydroxy-4-methylthio butanoic acid) ${ }_{2}$ or $\mathrm{CuSO}_{4}$. Results indicated that $\mathrm{Cu}$ (2-hydroxy-4-methylthio butanoic acid) $)_{2}$ was more efficient than $\mathrm{CuSO}_{4}$ in improving feed efficiency [122]. Another source of inorganic $\mathrm{Cu}$ is $\mathrm{Cu}$ hydroxychloride, and several experiments demonstrate that this source of $\mathrm{Cu}$, when included at $150 \mathrm{mg} / \mathrm{kg}$, enhances growth rate and feed efficiency in pigs (Table 3). Copper hydroxychloride is insoluble in water due to covalent binding of $\mathrm{Cu}$ to hydroxyl groups, but it is highly soluble in acidic conditions, which makes it less reactive

Table 3 Growth performance of pigs fed diets containing 0 or $150 \mathrm{mg}$ Cu per kg from Cu hydroxychloride. Average of 7 experiments $^{a}$

\begin{tabular}{|c|c|c|c|c|}
\hline \multirow[t]{2}{*}{ Item } & \multicolumn{2}{|l|}{ Diet } & \multirow[t]{2}{*}{ SEM } & \multirow[t]{2}{*}{$P$-value } \\
\hline & Control & Control $+\mathrm{Cu}^{\mathrm{b}}$ & & \\
\hline \multicolumn{5}{|l|}{ d 0 to 14} \\
\hline Initial body weight, kg & 9.641 & 9.629 & 1.552 & 0.745 \\
\hline $\mathrm{ADG}^{\mathrm{C}}, \mathrm{kg}$ & 0.319 & 0.376 & 0.082 & 0.002 \\
\hline $\mathrm{ADFl}^{\mathrm{c}}, \mathrm{kg}$ & 0.590 & 0.611 & 0.149 & 0.058 \\
\hline $\mathrm{G}: \mathrm{F}^{\mathrm{c}}$ & 0.557 & 0.636 & 0.046 & 0.015 \\
\hline Final body weight, kg & 15.415 & 16.223 & 2.947 & 0.004 \\
\hline \multicolumn{5}{|l|}{ d 14 to 28} \\
\hline $\mathrm{ADG}, \mathrm{kg}$ & 0.596 & 0.625 & 0.072 & 0.044 \\
\hline ADFl, kg & 1.029 & 1.018 & 0.144 & 0.846 \\
\hline G:F & 0.595 & 0.621 & 0.024 & 0.286 \\
\hline Final body weight, kg & 22.675 & 23.857 & 4.111 & 0.001 \\
\hline \multicolumn{5}{|l|}{ d 0 to 28} \\
\hline ADG, kg & 0.458 & 0.498 & 0.021 & $<0.001$ \\
\hline ADFI, kg & 0.807 & 0.814 & 0.154 & 0.817 \\
\hline G:F & 0.589 & 0.623 & 0.026 & 0.046 \\
\hline
\end{tabular}

axperiments included from [123-128]

${ }^{\mathrm{b}}$ The diet containing added $\mathrm{Cu}$ was fortified with $150 \mathrm{mg} / \mathrm{kg}$ of $\mathrm{Cu}$ from $\mathrm{Cu}$ hydroxychloride (IntelliBond CII; Micronutrients USA; Indianapolis, IN)

${ }^{C} A D G$ Average daily gain, $A D F I$ Average daily feed intake, G:F Gain to feed ratio 
in vitamin-mineral premixes, less toxic, and it has less pro-oxidant activity than $\mathrm{CuSO}_{4}[84,129,130]$.

The requirement for $\mathrm{Cu}$ by pigs is influenced by dietary factors and age of the animal. Neonatal pigs usually require 5 to $10 \mathrm{mg}$ of $\mathrm{Cu}$ per $\mathrm{kg}$ of diet for normal metabolism $[76,131,132]$ and as pigs get older, the requirement for $\mathrm{Cu}$ decreases. A requirement of 5 to $6 \mathrm{mg}$ of $\mathrm{Cu}$ per $\mathrm{kg}$ of diet has been suggested for growing pigs $[73,76]$. Both primiparous and multiparous sows require supplementation of $10 \mathrm{mg}$ of $\mathrm{Cu}$ per $\mathrm{kg}$ of diet during gestation [49]. Limited information is available about feeding high levels of $\mathrm{Cu}$ for gestating and lactating sows, but including 60 $\mathrm{mg}$ of $\mathrm{Cu}$ per $\mathrm{kg}$ of diet for sows improve reproductive performance compared with sows fed a diet containing 6 $\mathrm{mg} / \mathrm{kg}$ of $\mathrm{Cu}$ [76]. Sows fed diets containing $250 \mathrm{mg} / \mathrm{kg}$ of $\mathrm{Cu}$ from $\mathrm{CuSO}_{4}$ had reduced culling rate, farrowed larger litters of pigs, and had heavier pigs at birth and at weaning compared with sows fed diets without added $\mathrm{Cu}$ [133].

Dietary factors that interfere with $\mathrm{Cu}$ absorption, and therefore may influence the need for $\mathrm{Cu}$, include dietary $\mathrm{Zn}, \mathrm{Fe}, \mathrm{S}, \mathrm{Mo}$, and phytate. Zinc is closely related to $\mathrm{Cu}$, chemically and physiologically [134]. Zinc is an essential component and activator of several metalloenzymes, and some of these metalloenzymes, such as superoxide dismutase, has both $\mathrm{Cu}$ and $\mathrm{Zn}$ as one of its components [135]. High concentrations of dietary Zn increase the requirement for $\mathrm{Cu}$ [131] by inducing high concentrations of intestinal metallothionein, which binds $\mathrm{Cu}$, and decreases $\mathrm{Cu}$ absorption [36]. High $\mathrm{Zn}$ intake, therefore, induces clinical signs of $\mathrm{Cu}$ deficiency [136-138]. High dietary concentrations of $\mathrm{Fe}$ decrease $\mathrm{Cu}$ absorption, which lead to $\mathrm{Cu}$ deficiency [139]. It is believed that $\mathrm{Fe}$ and $\mathrm{Cu}$ have antagonistic effects due to competition for absorption sites in intestinal mucosa [139], and the interference of Fe in $\mathrm{Cu}$ absorption involve formation of ferrous sulfide complexes [140]. The sulfide part in the complex forms insoluble complexes with $\mathrm{Cu}$ [141]. The presence of phytate in the diet can also affect $\mathrm{Cu}$ absorption because phytic acid binds dietary cations including $\mathrm{Cu}$, rendering them unavailable for digestion and absorption [142]. Phytase supplementation, therefore, increases $\mathrm{Cu}$ absorption by releasing $\mathrm{Cu}$ from phytic acid [143], but microbial phytase may decrease $\mathrm{Cu}$ availability by releasing significant amounts of $\mathrm{Zn}$ bound to phytate [92].

\section{Growth promoting levels of copper}

Supplementing $\mathrm{Cu}$ to diets fed to weanling pigs at 100 to $250 \mathrm{mg} / \mathrm{kg}$ improve ADG and ADFI [108, 144, 145]. Reduction in diarrhea frequency and increased feed efficiency were also observed when high concentration of $\mathrm{Cu}$ was included in diets for weanling and growing pigs [123, 146]. Addition of 60 to $250 \mathrm{mg}$ of $\mathrm{Cu}$ per $\mathrm{kg}$ in sow diets during late gestation and lactation reduce preweaning mortality [147] and increase pig weaning weights
[148], presumably because of increased milk production. The greater ADFI reported for pigs fed diets supplemented with $\mathrm{Cu}$ is possibly due to the role of $\mathrm{Cu}$ in upregulating the mRNA expression of neuropeptide Y [149], a neuropeptide considered a feed intake inducer [150]. Copper also stimulates the secretion of growth hormone releasing hormone $[151,152]$ and is important for posttranslational modification of regulatory peptides [153]. One of the hypothesized mechanism of $\mathrm{Cu}$ in improving growth performance is that $\mathrm{Cu}$ may stimulate activities of enzymes involved in nutrient digestion [154]. Addition of high concentrations of $\mathrm{Cu}$ increased lipase and phospholipase A activities in the small intestine [155], which may result in increased absorption of fatty acids and improved growth performance. However, supplementation of $\mathrm{Cu}$ at $150 \mathrm{mg} / \mathrm{kg}$ in diets for growing pigs did not improve apparent total tract digestibility of energy or true total tract digestibility of fat $[124,125]$. Inclusion of $45 \mathrm{mg}$ of $\mathrm{Cu}$ per $\mathrm{kg}$ of diet improved body weight gain of rabbits by upregulating the mRNA transcription of fatty acid transport protein and fatty acid-binding protein (FABP), and carnitine palmitoyl transferase 1 [156]. Supplementation of $\mathrm{Cu}$ to diets increased lipogenesis and fatty acid uptake in fish, indicating that dietary $\mathrm{Cu}$ influences post-absorptive metabolism of lipids [157]. Copper supplementation in diets for finishing pigs did not affect mRNA transcription of intestinal CTR1 and FABP [158]. However, supplementation of $\mathrm{Cu}$ at $150 \mathrm{mg} / \mathrm{kg}$ in diets for growing pigs increased the abundance of lipoprotein lipase and FABP1 in the subcutaneous adipose tissue and liver, respectively [126]. Therefore, the observed improvement in growth performance of pigs fed the $\mathrm{Cu}$-supplemented diets may be a result of improved lipid metabolism with a subsequent improvement in energy utilization [126].

The growth-promoting effects of dietary $\mathrm{Cu}$ have also been attributed to its bacteriostatic and bactericidal properties [109] because $\mathrm{Cu}$ may alter the bacterial populations in the intestine, and thereby affect the growth and community structure of microorganisms in the cecum and colon [159]. Copper alters the 3-dimensional structure of bacterial proteins, which prevents bacteria from performing their normal functions [160]. Copper may disrupt enzyme structures and functions of bacteria by binding to $\mathrm{S}$ or carboxylate-containing groups and amino groups of proteins [161]. A high-Cu diet did not improve growth performance of germ-free pigs, but the high-Cu diet increased ADG and ADFI in conventionally reared pigs [162]. Clostridium, Escherichia coli, and Salmonella viable counts were reduced in the small intestine, and the numbers of coliforms were reduced as well in the cecum and colon of pigs upon $\mathrm{Cu}$ supplementation $[106,107,163]$. Copper supplementation in weanling pig diets reduced the counts of enterococci in the stomach and increased the lactobacilli population in the 
cecum of young pigs $[159,164]$. Reduction in concentration of lactate, short chain fatty acids, biogenic amines (histamine, cadaverine, and putrescine), ammonia absorption, and urease activity in the gastrointestinal content of pigs were observed if 175 to $250 \mathrm{mg}$ of $\mathrm{CuSO}_{4}$ per $\mathrm{kg}$ was supplemented to diets for weanling pigs $[159,163,165$, 166]. Supplementation of $150 \mathrm{mg} / \mathrm{kg} \mathrm{Cu}$ as $\mathrm{Cu}$ hydroxychloride in diets for growing pigs also resulted in a reduction in microbial protein concentration, which is likely due to the ability of $\mathrm{Cu}$ to inhibit growth of microbes in the intestinal tract of pigs [167].

Weanling pigs are susceptible to infections, diseases, and villous atrophy in the gut, which result in physiological and pathological changes and altered intestinal tight junction barrier resulting in increased intestinal permeability $[168,169]$. Tight junctions are made up of integral membrane proteins, mainly occludin and zonula occludens protein-1, and the integrity of the tight junctions is one of the important components of the intestinal mucosal barrier function [170]. Intestinal permeability increases upon diarrhea, which allows entry of toxins and pathogenic microorganism through the epithelial cells [171]. Inclusion of $\mathrm{Cu}$ at 100 to $200 \mathrm{mg} / \mathrm{kg}$ in diets fed to weanling pigs increases villus height and reduces crypt depth, thus improving intestinal health [172]. A reduction in concentrations of plasma diamine oxidase and $D$ lactate was observed when diets were supplemented with $\mathrm{Cu}$-exchanged montmorillonites at $1500 \mathrm{mg} / \mathrm{kg}$ [163]. Diamine oxidase is located exclusively in intestinal villus and its preference in blood plasma serves as a marker for mucosal injury [173]. When pigs undergo stress and intestinal mucosal barrier is damaged, intestinal mucosal cells are being sloughed into the lumen, which leads to increased concentration of diamine oxidase [163]. Plasma $D$-lactate is a byproduct of intestinal bacteria, and excessive production of this metabolite pass through the damaged mucosa [173]. Therefore, the observed reduction in plasma diamine oxidase and $D$-lactate upon supplementation of dietary of $\mathrm{Cu}$ to diets indicates reduction in intestinal permeability and improvement of intestinal health. However, this is in contrast with data indicating that supplementation of $\mathrm{Cu}$ hydroxychloride did not affect the lactulose: mannitol ratio in pigs [127] indicating that high concentration of dietary $\mathrm{Cu}$ did not impact intestinal permeability of pigs.

Copper plays an important role in improving the innate and acquired immune function of animals [174], but improvements in the immune status of pigs fed high- $\mathrm{Cu}$ diets may be indirect because of the bacteriostatic property of $\mathrm{Cu}$, which may reduce inflammation caused by pathogens [123, 174]. Exposure of pigs to pathogenic or nonpathogenic antigens results in an activated immune system and subsequent release of cytokines such as tumor necrosis factor $\alpha$, interleukin-1, and interleukin-6 [168]. Pigs fed diets containing $3000 \mathrm{mg}$ of $\mathrm{Zn}$ per $\mathrm{kg}$ and $250 \mathrm{mg}$ of $\mathrm{Cu}$ per $\mathrm{kg}$ had reduced plasma cytokine circulation after a coliform lipopolysaccharide challenge, which likely indicates that both $\mathrm{Cu}$ and $\mathrm{Zn}$ can reduce infection and alleviate stress responses induced by bacterial endotoxin [175]. Likewise, pigs fed diets containing nanoCu had greater ADG and feed efficiency, and greater concentrations of $\gamma$-globulin, total globulin protein, and IgG compared with pigs fed the control diet [176]. Supplementation of dietary $\mathrm{Cu}$ to diets also resulted in reduced tumor necrosis factor $\alpha$ concentration and increased activity of superoxide dismutase in blood serum of weanling pigs $[123,176]$. This indicates that the observed improvement in growth performance in pigs fed the $\mathrm{Cu}$-supplemented diets was possibly due to improved antioxidant capacity and humoral immune response, which can prevent susceptibility of pigs to infections and diseases.

\section{Conclusions}

Copper is an important micronutrient needed for maintenance, growth, and optimum health. Inclusion of 75 to $250 \mathrm{mg} / \mathrm{kg}$ of $\mathrm{Cu}$ in diets for pigs improve feed intake and feed efficiency. Results of several experiments demonstrated that the consistent improvement in growth performance upon $\mathrm{Cu}$ supplementation to diets is likely a result of the ability of dietary $\mathrm{Cu}$ to modulate intestinal microbial populations, increase lipase activity, stimulate secretion of neuropeptide $\mathrm{Y}$ and growth hormone, regulate antioxidant system, indirectly improve the immune response, and increase mRNA abundance of genes involved in post-absorptive metabolism of lipids in pigs. Dietary factors that interfere with $\mathrm{Cu}$ absorption was discussed, but further research needs to focus on determining potential interactions of $\mathrm{Cu}$ with non-nutritive feed additives (e.g., enzymes, probiotics). The optimum amount and duration of feeding supplemental $\mathrm{Cu}$ in diets fed to pigs also need to be further investigated. By addressing these gaps in the knowledge about $\mathrm{Cu}$, the use of $\mathrm{Cu}$ in the feeding of pigs can be optimized.

\begin{abstract}
Abbreviations
ADFI: Average daily feed intake; ADG: Average daily gain; ATOX1: Antioxidant protein 1; ATP7A: Copper transporting ATPase 1 protein; ATP7B: Copper transporting ATPase 2 protein; AST: Aspartate transaminase; CTR1: Copper transport protein 1; CTR2: Copper transport protein 2; COX17: Cytochrome C oxidase Cu chaperone; DMT1: Divalent metal transporter; G:F: Gain to feed ratio; SOD1: Cytosolic Cu-Zn superoxide dismutase; SOD3: Extracellular $\mathrm{Cu}-\mathrm{Zn}$ superoxide dismutase 3
\end{abstract}

Acknowledgements

Not applicable.

Authors' contributions

HHS conceived the manuscript's purpose and critically revised the manuscript. CDE wrote and revised the manuscript. Both authors read and approved the final manuscript. 


\section{Funding}

Not applicable.

\section{Availability of data and materials}

Not applicable.

\section{Ethics approval and consent to participate}

Not applicable.

\section{Consent for publication}

Not applicable.

\section{Competing interests}

The authors declare that they have no competing interests.

Received: 5 June 2020 Accepted: 22 November 2020

Published online: 11 January 2021

\section{References}

1. Suttle NF. Mineral nutrition of livestock. 4th ed. Oxfordshire: CABI Publishing; 2010.

2. Ammerman $\mathrm{CB}$, Goodrich RD. Advances in mineral nutrition in ruminants. J Anim Sci. 1983:57:519-33.

3. McCollum EV. A history of nutrition. Boston: Houghton Mifflin Co.; 1957.

4. Mateos GG, Lazaro R, Astillero JR, Perez-Serrano M. Trace minerals: what text books don't tell you. In: Taylor-Pickard JA, Tucker LA, editors. Re-defining mineral nutrition. Nottingham: Nottingham Univ. Press; 2005. p. 21-61.

5. Goff JP. Minerals, bones, and joints. In: Reece WO, editor. Duke's physiology of domestic animals. Oxford: Wiley; 2015. p. 581-3.

6. McDowell LR. Copper and molybdenum. In: Cunha TJ, editor. Minerals in animal and human nutrition. San Diego: Academic; 1992. p. 176-202.

7. Crapo JD, Oury T, Rabouille C, Slot JW, Chang LY. Copper-zinc superoxide dismutase is primarily a cytosolic protein in human cells. Proc Natl Acad Sci U S A. 1992:89:10405-9.

8. Manto M. Abnormal copper homeostasis: mechanisms and roles in neurodegeneration. Toxics. 2014:2:327-45.

9. Hill GM. Minerals and mineral utilization in swine. In: Chiba LI, editor Sustainable swine nutrition. Oxford: Blackwell Publishing Ltd; 2013. p. 186-9.

10. Turnlund JR. Human whole-body copper metabolism. Am J Clin Nutr. 1998; 67:960S-4S

11. Gaetke LM, Chow CK. Copper toxicity, oxidative stress, and antioxidant nutrients. Toxicology. 2003;189:147-63.

12. Hart EB, Steenbock H, Waddell J, Elvehjem CA. Iron in nutrition. VII. Copper as a supplement to iron for hemoglobin building in the rat. J Biol Chem. 1928:77:797-812.

13. Elvehjem CA. The biological significance of copper and its relation to iron metabolism. Physiol Rev. 1935;15:471-507.

14. Hambridge KM, Casey CE, Krebs NF. Zinc. In: Mertz W, editor. Trace elements in human and animal nutrition. New York: Academic; 1986. p. 1-138.

15. Lebel A, Matte JJ, Guay F. Effect of mineral source and mannan oligosaccharide supplements on zinc and copper digestibility in growing pigs. Arch Anim Nutr. 2014;68:370-84

16. Liu Y, Ma YL, Zhao JM, Vazquez-Añón M, Stein HH. Digestibility and retention of zinc, copper, manganese, iron, calcium, and phosphorus in pigs fed diets containing inorganic or organic minerals. J Anim Sci. 2014;92: 3407-15.

17. Richards JD, Zhao J, Harrell RJ, Atwell CA, Dibner JJ. Trace mineral nutrition in poultry and swine. Asian-Australas J Anim Sci. 2010;23:1527-34

18. Underwood EJ, Suttle NF. The mineral nutrition of livestock. 3rd ed. Oxfordshire: CABI Publishing; 1999.

19. Powell JJ, Whitehead MW, Ainley CC, Kendall MD, Nicholson JK, Thompson $\mathrm{RPH}$. Dietary minerals in the gastrointestinal tract: hydroxypolymerisation of aluminium is regulated by luminal mucins. J Inorg Biochem. 1999;75:167-80.

20. Mullan BP, D'Souza DN. The role of organic minerals in modern pig production. In: Taylor JA, Tucker LA, editors. Re-defining mineral nutrition. Nottingham: Nottingham Univ. Press; 2005. p. 89-106.

21. van Campen DR, Mitchell EA Absorption of Cu-64, Zn-65, Mo-99, and Fe-59 from ligated segments of the rat gastrointestinal tract. J Nutr. 1965;86:120-4.

22. van den Berghe PVE, Klomp LWJ. New developments in the regulation of intestinal copper absorption. Nutr Rev. 2009;67:658-72.
23. Pappenheimer JR, Reiss KZ. Contribution of solvent drag through intercellular junctions to absorption of nutrients by the small intestine of the rat. J Membr Biol. 1987;100:123-36.

24. Georgatsou E, Mavrogiannis LA, Fragiadakis GS, Alexandraki D. The yeast fre $1 p / f r e 2 p$ cupric reductases facilitate copper uptake and are regulated by the copper-modulated mac1p activator. J Biol Chem. 1997;272:13786-92.

25. Ohgami RS, Campagna DR, McDonald A, Fleming MD. The Steap proteins are metalloreductases. Blood. 2006;108:1388.

26. Lee J, Petris MJ, Thiele DJ. Characterization of mouse embryonic cells deficient in the ctr1 high affinity copper transporter identification of a Ctr1independent copper transport system. J Biol Chem. 2002;277:40253-9.

27. Hill GM, Link JE. Transporters in the absorption and utilization of zinc and copper. J Anim Sci. 2009:87:E85-9.

28. Zhou B, Gitschier J. hCTR1: a human gene for copper uptake identified by complementation in yeast. Proc Natl Acad Sci. 1997:94:7481-6.

29. Cater MA, Mercer JFB. Copper in mammals: mechanisms of homeostasis and pathophysiology. In: Tamas MJ, Martinoia E, editors. Molecular biology of metal homeostasis and detoxification: from microbes to man. Berlin, Heidelberg: Springer Berlin Heidelberg; 2006. p. 101-29.

30. Vonk WI, Wijmenga C, van de Sluis B. Relevance of animal models for understanding mammalian copper homeostasis. Am J Clin Nutr. 2008:88: 840S-5S.

31. Lutsenko S, Barnes NL, Bartee MY, Dmitriev OY. Function and regulation of human copper-transporting ATPases. Physiol Rev. 2007;87:1011-46.

32. Kim H, Son H-Y, Bailey SM, Lee J. Deletion of hepatic Ctr1 reveals its function in copper acquisition and compensatory mechanisms for copper homeostasis. Am J Physiol Gastrointest Liver Physiol. 2009;296:G356-G64.

33. Axelsen KB, Palmgren MG. Evolution of substrate specificities in the P-type ATPase superfamily. J Mol Evol. 1998;46:84-101.

34. Peña MM, Jaekwon OL, Thiele DJ. A delicate balance: homeostatic control of copper uptake and distribution. J Nutr. 1999;129:1251-60.

35. Davis GK, Mertz W. Copper. In: Mertz W, editor. Trace elements in human and animal nutrition. San Diego: Academic; 1987. p. 301-64.

36. Cousins RJ. Absorption, transport, and hepatic metabolism of copper and zinc: special reference to metallothionein and ceruloplasmin. Physiol Rev. 1985:65:238-309.

37. Carlson MS, Hill GM, Link JE. Early- and traditionally weaned nursery pigs benefit from phase-feeding pharmacological concentrations of zinc oxide: effect on metallothionein and mineral concentrations. J Anim Sci. 1999;77: 1199-207.

38. Toriumi S, Saito T, Hosokawa T, Takahashi Y, Numata T, Kurasaki M. Metal binding ability of metallothionein-3 expressed in Escherichia coli. Basic Clin Pharmacol Toxicol. 2005:96:295-301.

39. Huang Y, Ashwell M, Fry R, Lloyd K, Flowers W, Spears J. Effect of dietary copper amount and source on copper metabolism and oxidative stress of weanling pigs in short-term feeding. J Anim Sci. 2015;93:2948-55.

40. Goff JP. Invited review: mineral absorption mechanisms, mineral interactions that affect acid-base and antioxidant status, and diet considerations to improve mineral status. J Dairy Sci. 2018;101:2763-813.

41. Linder MC. Biochemistry of copper. New York: New York Plenum Press; 1991.

42. Roeser HP, Lee GR, Nacht S, Cartwright GE. The role of ceruloplasmin in iron metabolism. J Clin Invest. 1970;49:2408-17.

43. Osaki S, Johnson DA, Frieden E. The possible significance of the ferrous oxidase activity of ceruloplasmin in normal human serum. J Biol Chem. 1966:241:2746-51.

44. Ragan HA, Nacht S, Lee GR, Bishop CR, Cartwright GE. Effect of ceruloplasmin on plasma iron in copper-deficient swine. Am J Phys. 1969; 217:1320-3.

45. Milne DB, Matrone G. Forms of ceruloplasmin in developing piglets. Biochim Biophys Acta. 1970;212:43-9.

46. Gubler CJ, Brown H, Markowitz H, Cartwright GE, Wintrobe MM. Studies on copper metabolism. XXIII: portal (Laennec's) cirrhosis of the liver. J Clin Invest. 1957;36:1208-16.

47. Gubler CJ, Lahey ME, Cartwright GE, Wintrobe MM. Studies on copper metabolism. $X$ : factors influencing the plasma copper level of the albino rat. Am J Phys. 1952;171:652-8.

48. Lahey ME, Gubler CJ, Chase MS, Cartwright GE, Wintrobe MM. Studies on copper metabolism. II: hematologic manifestations of copper deficiency in swine. Blood. 1952;7:1053-74.

49. Lorenzen EJ, Smith SE. Copper and manganese storage in the rat, rabbit, and guinea pig. J Nutr. 1947;33:143-54. 
50. Hart EB, Steenbock H, Waddell J, Elvehjem CA. Iron in nutrition VII. Copper as a supplement to iron for hemoglobin building in the rat. Nutr Rev. 1987; 45:181-3.

51. Suttle NF, Angus KW. Effects of experimental copper deficiency on the skeleton of the calf. J Comp Pathol. 1978;88:137-48.

52. Carla LGG. Copper levels in livers of turkeys with naturally occurring aortic rupture. Avian Dis. 1977;21:113-6.

53. Savage JE, Bird DW, Reynolds G, O'Dell BL. Comparison of copper deficiency and lathyrism in turkey poults. J Nutr. 1966;88:15-25.

54. Coulson WF, Carnes WH. Cardiovascular studies on copper-deficient swine. v. the histogenesis of the coronary artery lesions. Am J Pathol. 1963;43:945-54.

55. Carnes WH, Coulson WF, Albino AM. Intimal lesions in muscular arteries of young copper-deficient swine. Ann N Y Acad Sci. 1965;127:800-10.

56. Buffoni F, Blaschko HKF. Benzylamine oxidase and histaminase: purification and crystallization of an enzyme from pig plasma. Proc R Soc Lond B Biol Sci. 1964;161:153-67.

57. Prohaska JR. Changes in tissue growth, concentrations of copper, iron, cytochrome oxidase and superoxide dismutase subsequent to dietary or genetic copper deficiency in mice. J Nutr. 1983;113:2048-58.

58. Miller ER, Stowe HD, Ku PK, Hill GM. Copper and zinc in animal nutrition. Literature Review Committee. West Des Moines: National Feed Ingredients Association; 1979.

59. Sorenson JRJ. Copper complexes offer a physiological approach to treatment of chronic diseases. In: Ellis GP, West GB, editors. Progress in medicinal chemistry: Elsevier; 1989. p. 437-568..

60. Segal AW, Meshulam T. Production of superoxide by neutrophils: a reappraisal. FEBS Lett. 1979;100:27-32.

61. Teague HS, Carpenter LE. The demonstration of a copper deficiency in young growing pigs: five figures. J Nutr. 1951;43:389-99.

62. Pletcher JM, Banting LF. Copper deficiency in piglets characterized by spongy myelopathy and degenerative lesions in the great blood vessels. I S Afr Vet Assoc. 1983:54:43-6.

63. Johnson LR, Engle TE. The effects of copper source and concentration on lipid metabolism in growing and finishing angus steers. Asian-Australas J Anim Sci. 2003;16:1131-6.

64. Kaya A, Altiner A, Ozpinar A. Effect of copper deficiency on blood lipid profile and haematological parameters in broilers. J Vet Med. 2006;53: 399-404.

65. Dove CR. The effect of adding copper and various fat sources to the diets of weanling swine on growth performance and serum fatty acid profiles. $J$ Anim Sci. 1993;71:2187-92.

66. Elliot Jl, Bowland JP. Effects of dietary copper sulfate on the fatty acid composition of porcine depot fats. J Anim Sci. 1968;27:956-60.

67. Wu F, Woodworth JC, DeRouchey JM, Coble KF, Tokach MD, Goodband RD, et al. Effect of standardized ileal digestible lysine and added copper on growth performance, carcass characteristics, and fat quality of finishing pigs. J Anim Sci. 2018:96:3249-63.

68. Carr TP, Lei KY. In vivo apoprotein catabolism of high density lipoproteins in copper-deficient, hypercholesterolemic rats. Proc Soc Exp Biol Med. 1989; 191:370-6.

69. Burkhead JL, Lutsenko S. The role of copper as a modifier of lipid metabolism. In: Baez RV, editor. Lipid metabolism. Rijeka: InTech; 2013. p. Ch. 03.

70. Meagher EA, FitzGerald GA. Indices of lipid peroxidation in vivo: strengths and limitations. Free Radic Biol Med. 2000;28:1745-50.

71. Abdel-Mageed AB, Oehme FW. A review of the biochemical roles, toxicity and interactions of zinc, copper and iron: II. Copper. Vet Hum Toxicol. 1990; 32:230-4.

72. Lamand M. Copper toxicity in sheep. In: L'hermite P, Dehandtschutter J, editors. Copper in animal wastes and sewage sludge. London: D. Reidel Publishing Co.; 1981. p. 261-72

73. ARC. The nutrient requirements of pigs. Slough: Commonwealth; 1981.

74. Suttle NF, Alloway BJ, Thornton I. Effect of soil ingestion on the utilization of dietary copper by sheep. J Agric Sci. 1975;84:249-54.

75. Thompson LJ. Copper. In: Gupta RC, editor. Veterinary toxicology (third edition): Academic; 2018. p. 425-7.

76. NRC. Nutrient requirements of swine. 11th rev. ed. Washington, D.C.: Natl. Acad. Press; 2012

77. Jacela JY, DeRouchey JM, Tokach MD, Goodband RD, Nelssen JL, Renter DG, et al. Feed additives for swine: fact sheets - high dietary levels of copper and zinc for young pigs, and phytase. J Swine Health Prod. 2010;18:87-91.
78. Suttle NF, Mills CF. Studies of the toxicity of copper to pigs: 1. Effects of oral supplements of zinc and iron salts on the development of copper toxicosis. Br J Nutr. 2007;20:135-48.

79. Ellingsen DG, Horn N, Aaseth JAN. Copper. In: Nordberg GF, Fowler BA, Nordberg M, Friberg LT, editors. Handbook on the toxicology of metals. Burlington: Academic; 2007. p. 529-46.

80. Bremner I. Manifestations of copper excess. Am J Clin Nutr. 1998;67:1069-73.

81. Lykkesfeldt J, Svendsen O. Oxidants and antioxidants in disease: oxidative stress in farm animals. Vet J. 2007;173:502-11.

82. Fry RS, Ashwell MS, Lloyd KE, O'Nan AT, Flowers WL, Stewart KR, et al. Amount and source of dietary copper affects small intestine morphology, duodenal lipid peroxidation, hepatic oxidative stress, and mRNA expression of hepatic copper regulatory proteins in weanling pigs. J Anim Sci. 2012;90: 3112-9.

83. Khoubnasabjafari M, Ansarin K, Jouyban A. Reliability of malondialdehyde as a biomarker of oxidative stress in psychological disorders. Bioimpacts. 2015; 5:123-7.

84. Miles RD, O'Keefe SF, Henry PR, Ammerman CB, Luo XG. The effect of dietary supplementation with copper sulfate or tribasic copper chloride on broiler performance, relative copper bioavailability, and dietary prooxidant activity. Poult Sci. 1998:77:416-25.

85. Baker DH, Ammerman CB. Copper bioavailability. In: Ammerman CB, Baker $\mathrm{DH}$, Lewis AJ, editors. Bioavailability of nutrients for animals. San Diego: Academic; 1995. p. 127-56.

86. O'Dell BL. Bioavailability of essential and toxic trace elements. Fed Proc. 1983:42:1714-8

87. Littell RC, Lewis AJ, Henry PR. Statistical evaluation of bioavailability assays. In: Ammerman CB, Baker DH, Lewis AJ, editors. Bioavailabiltiy of nutrients for animals. San Diego: Academic; 1995. p. 5-33.

88. Aoyagi S, Baker DH, Wedekind KJ. Estimates of copper bioavailability from liver of different animal species and from feed ingredients derived from plants and animals. Poult Sci. 1993;72:1746-55.

89. L'Abbé MR, Fischer PWF. The effects of high dietary zinc and copper deficiency on the activity of copper-requiring metalloenzymes in the growing rat. J Nutr. 1984;114:813-22.

90. Suttle NF. A technique for measuring the biological availability of copper of sheep, sing hypocupraemic ewes. Br J Nutr. 2007;32:395-405.

91. Lönnerdal B, Bell J, Keen C. Copper absorption from human milk, cow's milk, and infant formulas using a suckling rat model. Am J Clin Nutr. 1985;42: 836-44.

92. Aoyagi S, Baker DH. Effect of microbial phytase and 1,25-dihydroxycholecalciferol on dietary copper utilization in chicks. Poult Sci. 1995;74:121-6.

93. Cromwell GL, Stahly TS, Monegue HJ. Effects of source and level of copper on performance and liver copper stores in weanling pigs. J Anim Sci. 1989; 67:2996-3002.

94. Lo GS, Settle SL, Steinke FH. Bioavailability of copper in isolated soybean protein using the rat as an experimental model. J Nutr. 1984;114:332-40.

95. Kegley EB, Spears JW. Bioavailability of feed-grade copper sources (oxide, sulfate, or lysine) in growing cattle. J Anim Sci. 1994;72:2728-34.

96. Baker DH. Cupric oxide should not be used as a copper supplement for either animals or humans. J Nutr. 1999:129:2278-9.

97. Kong C, Park CS, Kim BG. Effects of an enzyme complex on in vitro dry matter digestibility of feed ingredients for pigs. Springerplus. 2015;4:261.

98. Pang Y, Applegate TJ. Effects of copper source and concentration on in vitro phytate phosphorus hydrolysis by phytase. J Agric Food Chem. 2006;54:1792-6.

99. Park CS, Kim BG. In vitro solubility of copper(II) sulfate and dicopper chloride trihydroxide for pigs. Asian-Austral J Anim. 2016;29:1608-15.

100. Pang Y, Applegate TJ. Effects of dietary copper supplementation and copper source on digesta $\mathrm{pH}$, calcium, zinc, and copper complex size in the gastrointestinal tract of the broiler chicken. Poult Sci. 2007;86:531-7.

101. O'Dell BL. Mineral availability and metal binding constituents of the diet. Ithaca: Proc. Cornell Nutr. Conf. Feed Manufact; 1962.

102. Drew MD, Borgeson TL, Thiessen DL. A review of processing of feed ingredients to enhance diet digestibility in finfish. Anim Feed Sci Technol. 2007;138:118-36.

103. Milligan D, Moyer H. Crystallization in the copper sulphate- sulphuric acidwater system. Eng Min J. 1975;176:85-9.

104. Justel FJ, Claros M, Taboada ME. Solubilities and properties of saturated solutions in the copper sulfate + sulfuric acid + seawater system at different temperatures. Braz J Chem Eng. 2015;32:629-35. 
105. Shelton NW, Tokach MD, Nelssen JL, Goodband RD, Dritz SS, DeRouchey JM, et al., editors. Effects of copper sulfate and zinc oxide on weanling pig growth and plasma mineral levels. In: Swine Day: Kansas State University; 2009.

106. Ma YL, Guo T, Xu ZR. Effect of Cu (II)-exchange montmorillonite on diarrhea incidence, intestinal microflora and mucosa morphology of weaning pigs. Chin J Vet Sci. 2007:27:279-83.

107. Ma YL, Xu ZR, Guo T. Effect of inorganic copper/montmorillonite nanomaterial on growth performance, intestinal microbial flora and bacterial enzyme activities in broilers. Chin J Anim Sci. 2006;42:28-31.

108. Perez VG, Waguespack AM, Bidner TD, Southern LL, Fakler TM, Ward TL, et al. Additivity of effects from dietary copper and zinc on growth performance and fecal microbiota of pigs after weaning. J Anim Sci. 2011; 89:414-25.

109. Stahly TS, Cromwell GL, Monegue HJ. Effects of the dietary inclusion of copper and(or) antibiotics on the performance of weanling pigs. J Anim Sci. 1980;51:1347-51

110. Wang YZ, Shan TZ, Xu ZR, Feng J, Wang ZQ. Effects of the lactoferrin (LF) on the growth performance, intestinal microflora and morphology of weanling pigs. Anim Feed Sci Technol. 2007;135:263-72.

111. Zhao J, Allee G, Gerlemann G, Ma L, Gracia Ml, Parker D, et al. Effects of a chelated copper as growth promoter on performance and carcass traits in pigs. Asian-Austral J Anim. 2014;27:965-73.

112. Lin G, Guo Y, Liu B, Wang R, Su X, Yu D, et al. Optimal dietary copper requirements and relative bioavailability for weanling pigs fed either copper proteinate or tribasic copper chloride. J Anim Sci Biotechnol. 2020;11:54.

113. Hasman H, Aarestrup FM. Relationship between copper, glycopeptide, and macrolide resistance among Enterococcus faecium strains isolated from pigs in Denmark between 1997 and 2003. Antimicrob Agents Chemother. 2005; 49:454-6.

114. Leelawatcharamas V, Chia LG, Charoenchai P, Kunajakr N, Liu CQ, Dunn NW. Plasmid-encoded copper resistance in Lactococcus lactis. Biotechnol Lett. 1997:19:639-43.

115. Solioz M, Abicht HK, Mermod M, Mancini S. Response of gram-positive bacteria to copper stress. J Biol Inorg Chem. 2009;15:3.

116. Brown NL, Barrett SR, Camakaris J, Lee BTO, Rouch DA. Molecular genetics and transport analysis of the copper-resistance determinant (pco) from Escherichia coli plasmid pRJ1004. Mol Microbiol. 1995;17:1153-66.

117. Fouad MT. The physiochemical role of chelated minerals in maintaining optimal body biological functions. J App Nutr. 1976;28:5.

118. Stansbury WF, Tribble LF, Orr DE. Effect of chelated copper sources on performance of nursery and growing pigs. J Anim Sci. 1990;68:1318-22.

119. van Heugten E, Coffey MT. Efficacy of copper-lysine chelate as growth promotant in weanling swine. J Anim Sci. 1992;70(Suppl. 1):18 (Abstr.)

120. Coffey RD, Cromwell GL, Monegue HJ. Efficacy of a copper-lysine complex as a growth promotant for weanling pigs. J Anim Sci. 1994;72:2880-6.

121. Windisch WM, Gotterbarm GG, Roth FX. Effect of potassium diformate in combination with different amounts and sources of excessive dietary copper on production performance in weaning piglets. Arch Anim Nutr. 2001:54:87-100.

122. Ma YL, Zanton Gl, Zhao J, Wedekind K, Escobar J, Vazquez-Añón M. Multitrial analysis of the effects of copper level and source on performance in nursery pigs. J Anim Sci. 2015;93:606-14.

123. Espinosa CD, Fry RS, Usry JL, Stein HH. Effects of copper hydroxychloride and choice white grease on growth performance and blood characteristics of weanling pigs kept at normal ambient temperature or under heat stress. Anim Feed Sci Technol. 2019;256:114257.

124. Espinosa CD, Fry RS, Usry JL, Stein HH. Copper hydroxychloride improves growth performance and reduces diarrhea frequency of weanling pigs fed a corn-soybean meal diet but does not change apparent total tract digestibility of energy and acid hydrolyzed ether extract. J Anim Sci. 2017; 95:5447-54

125. Espinosa CD, Fry RS, Kocher M, Stein HH. Effects of copper hydroxychloride and increasing concentrations of dietary fat on growth performance, total tract endogenous loss of fat, and apparent total tract digestibility of fat by growing pigs. J Anim Sci. 2019;97:68.

126. Espinosa CD, Fry RS, Kocher ME, Stein HH. Effects of copper hydroxychloride on growth performance and abundance of genes involved in lipid metabolism of growing pigs. J Anim Sci. 2020;98..

127. Espinosa CD, Fry RS, Kocher ME, Stein HH. Effects of copper hydroxychloride and dietary fiber on intestinal permeability, growth performance, and blood characteristics of nursery pigs. Anim Feed Sci Technol. 2020:114447.
128. Shelton NW, Nelssen JL, Hill GM, Tokach MD, Goodband RD, DeRouchey JM, et al., editors. Effects of copper sulfate, tri-basic copper chloride, and zinc oxide on weanling pig growth and plasma mineral concentrations. In: Swine Day: Kansas State University; 2008.

129. Fry RS, Hu W, Williams SB, Paton ND, Cook DR. Diet form and by-product level affect growth performance and carcass characteristics of grow-finish pigs. J Anim Sci. 2012;90(Suppl 3):380.

130. Liu Z, Bryant MM, Roland SDA. Layer performance and phytase retention as influenced by copper sulfate pentahydrate and tribasic copper chloride. J Appl Poult Res. 2005;14:499-505.

131. Underwood EJ. Trace elements in human and animal nutrition. 4th ed. New York: Academic; 1977.

132. Hill G, Ku P, Miller E, Ullrey D, Losty T, O'Dell B. A copper deficiency in neonatal pigs induced by a high zinc maternal diet. J Nutr. 1983;113:867-72.

133. Cromwell GL, Monegue HJ, Stahly TS. Long-term effects of feeding a high copper diet to sows during gestation and lactation. J Anim Sci. 1993;71: 2996-3002.

134. Hill GM, Brewer GJ, Hogikyan ND, Stellini MA. The effect of depot parenteral zinc on copper metabolism in the rat. J Nutr. 1984;114:2283-91.

135. O'Dell BL. Role of zinc in plasma membrane function. J Nutr. 2000;5:1432S-6S.

136. Bird DW. Copper deficiency and its effect upon reproduction, growth and connective tissue synthesis in avian species. Columbia: PhD Diss. Univ. Missouri; 1966.

137. Esparza Gonzalez BP, Fong RN, Gibson CJ, Fuentealba IC, Cherian MG. Zinc supplementation decreases hepatic copper accumulation in LEC rat. Biol Trace Elem Res. 2005;105:117-34.

138. Hill GM, Miller ER, Whetter PA, Ullrey DE. Concentration of minerals in tissues of pigs from dams fed different levels of dietary zinc. J Anim Sci. 1983;57:130-8.

139. Hedges JD, Kornegay ET. Interrelationship of dietary copper and iron as measured by blood parameters, tissue stores and feedlot performance of swine. J Anim Sci. 1973:37:1147-54

140. Collins JF, Prohaska JR, Knutson MD. Metabolic crossroads of iron and copper. Nutr Rev. 2010;68:133-47.

141. Suttle NF, Abrahams P, Thornton I. The role of a soil $\times$ dietary sulphur interaction in the impairment of copper absorption by ingested soil in sheep. J Agric Sci. 2009;103:81-6.

142. Martin CJ, Evans WJ. Phytic acid: divalent cation interactions: III. A calorimetric and titrimetric study of the $\mathrm{pH}$ dependence of copper(II) binding. J Inorg Biochem. 1986;28:39-55.

143. Adeola O. Digestive utilization of minerals by weanling pigs fed copperand phytase-supplemented diets. Can J Anim Sci. 1995;75:603-10.

144. Cromwell GL, Lindemann MD, Monegue HJ, Hall DD, Orr JDE. Tribasic copper chloride and copper sulfate as copper sources for weanling pigs. J Anim Sci. 1998:76:118-23.

145. Hill GM, Cromwell GL, Crenshaw TD, Dove CR, Ewan RC, Knabe DA, et al. Growth promotion effects and plasma changes from feeding high dietary concentrations of zinc and copper to weanling pigs (regional study). J Anim Sci. 2000:78:1010-6.

146. Barber RS, Braude R, Mitchell KG. Antibiotics and copper supplements for fattening pigs. Br J Nutr. 1955;9:378-81.

147. Thacker PA. Effect of high levels of copper or dichlorvos during late gestation and lactation on sow productivity. Can J Anim Sci. 1991;71:227-32.

148. Wallace HD, Houser RH, Combos GE, editors. High level copper supplementation of the sow during the farrowing and early lactation period. Gainesville: Florida Anim. Sci. Mimeograph Series; 1966.

149. Li J, Yan L, Zheng X, Liu G, Zhang N, Wang Z. Effect of high dietary copper on weight gain and neuropeptide $Y$ level in the hypothalamus of pigs. Trace Elem Med Biol. 2008;22:33-8.

150. Gehlert DR. Role of hypothalamic neuropeptide $Y$ in feeding and obesity. Neuropeptides. 1999;33:329-38.

151. Yang W, Wang J, Liu L, Zhu X, Wang X, Liu Z, et al. Effect of high dietary copper on somatostatin and growth hormone-releasing hormone levels in the hypothalami of growing pigs. Biol Trace Elem Res. 2011;143:893-900.

152. LaBella F, Dular R, Vivian S, Queen G. Pituitary hormone releasing or inhibiting activity of metal ions present in hypothalamic extracts. Biochem Bioph Res Co. 1973;52:786-91.

153. Eipper BA, Mains RE. Peptide a-Amidation. Annu Rev Physiol. 1988;50: 333-44.

154. Dove CR. The effect of copper level on nutrient utilization of weanling pigs. J Anim Sci. 1995;73:166-71. 
155. Luo XG, Dove CR. Effect of dietary copper and fat on nutrient utilization, digestive enzyme activities, and tissue mineral levels in weanling pigs. J Anim Sci. 1996;74:1888-96.

156. Lei L, Xiaoyi S, Fuchang L. Effect of dietary copper addition on lipid metabolism in rabbits. Food Nutr Res. 2017;61:1348866.

157. Chen F, Luo Z, Chen G-H, Shi X, Liu X, Song Y-F, et al. Effects of waterborne copper exposure on intestinal copper transport and lipid metabolism of Synechogobius hasta. Aquat Toxicol. 2016;178:171-81.

158. Coble KF, Burnett DD, DeRouchey JM, Tokach MD, Gonzalez JM, Wu F, et al. Effect of diet type and added copper on growth performance, carcass characteristics, energy digestibility, gut morphology, and mucosal mRNA expression of finishing pigs. J Anim Sci. 2018;96:3288-301.

159. Højberg O, Canibe N, Poulsen HD, Hedemann MS. Influence of dietary zinc oxide and copper sulfate on the gastrointestinal ecosystem in newly weaned pigs. Appl Environ Microbiol. 2005:71:2267-77.

160. Thurman RB, Gerba CP, Bitton G. The molecular mechanisms of copper and silver ion disinfection of bacteria and viruses. Crit Rev Environ Control. 1989; 18:295-315.

161. Sterritt RM, Lester JN. Interactions of heavy metals with bacteria. Sci Total Environ. 1980;14:5-17.

162. Shurson GC, Miller ER, Waxler GL, Yokoyama MT, Ku PK. Physiological relationships between microbiological status and dietary copper levels in the pig. J Anim Sci. 1990;68:1061-71.

163. Song J, Li Y, Hu C. Effects of copper-exchanged montmorillonite, as alternative to antibiotic, on diarrhea, intestinal permeability and proinflammatory cytokine of weanling pigs. Appl Clay Sci. 2013;77-78:52-5.

164. Wang M-Q, Du Y-J, Wang C, Tao W-J, He Y-D, Li H. Effects of copper-loaded chitosan nanoparticles on intestinal microflora and morphology in weaned piglets. Biol Trace Elem Res. 2012;149:184-9.

165. Dierick NA, Vervaeke IJ, Decuypere JA, Henderickx HK. Influence of the gut flora and of some growth-promoting feed additives on nitrogen metabolism in pigs. II. Studies in vivo. Livest Prod Sci. 1986;14:177-93.

166. Yen JT, Nienaber JA. Effects of high-copper feeding on portal ammonia absorption and on oxygen consumption by portal vein-drained organs and by the whole animal in growing pigs. J Anim Sci. 1993;71:2157-63.

167. Espinosa CD, Fry RS, Kocher ME, Stein HH. Effects of copper hydroxychloride and distillers dried grains with solubles on intestinal microbial concentration and apparent ileal and total tract digestibility of energy and nutrients by growing pigs. J Anim Sci. 2019;97:4904-11.

168. Al-Sadi R, Boivin M, Ma T. Mechanism of cytokine modulation of epithelial tight junction barrier. Front Biosci. 2009;14:2765-78.

169. Wijtten PJA, Meulen J, Verstegen MWA. Intestinal barrier function and absorption in pigs after weaning: a review. Br J Nutr. 2011;105:967-81.

170. Ballard ST, Hunter JH, Taylor AE. Regulation of tight-junction permeability during nutrient absorption across the intestinal epithelium. Annu Rev Nutr. 1995; 15:35-55.

171. Zhang B, Guo Y. Supplemental zinc reduced intestinal permeability by enhancing occludin and zonula occludens protein-1 (ZO-1) expression in weaning piglets. Br J Nutr. 2009;102:687-93.

172. Zhao J, Harper AF, Estienne MJ, Webb KE, McElroy AP, Denbow DM. Growth performance and intestinal morphology responses in early weaned pigs to supplementation of antibiotic-free diets with an organic copper complex and spray-dried plasma protein in sanitary and nonsanitary environments. J Anim Sci. 2007;85:1302-10.

173. Hu CH, Gu LY, Luan ZS, Song J, Zhu K. Effects of montmorillonite-zinc oxide hybrid on performance, diarrhea, intestinal permeability and morphology of weanling pigs. Anim Feed Sci Technol. 2012;177:108-15.

174. Prohaska JR, Failla ML. Copper and immunity. In: Klurfeld DM, editor Nutrition and immunology. Boston: Springer US; 1993. p. 309-32.

175. Namkung H, Gong J, Yu H, de Lange CFM. Effect of pharmacological intakes of zinc and copper on growth performance, circulating cytokines and gut microbiota of newly weaned piglets challenged with coliform lipopolysaccharides. Can J Anim Sci. 2006;86:511-22.

176. Gonzales-Eguia A, Fu C-M, Lu F-Y, Lien T-F. Effects of nanocopper on copper availability and nutrients digestibility, growth performance and serum traits of piglets. Livest Sci. 2009;126:122-9.

\section{Ready to submit your research? Choose BMC and benefit from:}

- fast, convenient online submission

- thorough peer review by experienced researchers in your field

- rapid publication on acceptance

- support for research data, including large and complex data types

- gold Open Access which fosters wider collaboration and increased citations

- maximum visibility for your research: over $100 \mathrm{M}$ website views per year

At BMC, research is always in progress.

Learn more biomedcentral.com/submissions 